УДК

\title{
АНАЛИЗ МЕТОДОВ УМЕНЬШЕНИЯ ТОКА И МОЩНОСТИ УТЕЧКИ В ЯЧЕЙКЕ SRAМ НА ОСНОВЕ FINFET ТРАНЗИСТОРОВ ${ }^{*}$
}

\author{
РАВИНДРА СИНГХ КУШВАХ, ВАНДНА СИКАРВАР
}

\author{
ITМ Университет, \\ Индия, Гвалиор
}

\begin{abstract}
Аннотация. Предложена ячейка статического оперативного запоминающего устройства SRAM (Static Random Access Memory) на основе 6 полевых транзисторов с вертикально расположенным затвором (FinFET транзистор). FinFET устройства использованы для улучшения рабочих характеристик, уменьшения тока и мощности утечки. Цель этой статьи заключается в снижении тока и мощности утечки ячейки SRAM на основе 6 FinFET транзисторов, используя различные методы 45-нм технологии. Разработана ячейка SRAM на основе 6 FinFET транзисторов и проведен анализ тока и мощности утечки. При разработке устройств памяти с низким потреблением наиболее важной проблемой является минимизация под-порогового тока утечки и тока утечки затвора. Эта работа предлагает метод, основанный на одновременной установке соответствующих значений порогового напряжения, толщины оксидного слоя затвора и напряжения источника питания с целью минимизации под-порогового тока утечки и тока утечки затвора в ячейке SRAM на основе 6 транзисторов. Результаты проведенного моделирования получены с помощью программы Cadence Virtuoso для 45-нм технологии
\end{abstract}

Ключевые слова: FinFET; ток утечки; потребляемая мощность; статическое оперативное запоминающее устройство; ОЗУ; под-пороговый ток утечки; ток утечки затвора

\section{ВВЕДЕНИЕ}

Снижение потребляемой мощности является одной из важных задач при разработке схем на основе комплементарных структур типа металл-оксид-полупроводник CMOS (КМОП). Перспективным способом снижения потребляемой мощности является снижение напряжения питания $V_{\mathrm{DD}}$. Однако при снижении напряжения питания увеличивается время задержки сигнала в логическом элементе и снижается рабочая частота. Недавно предло- жены два метода, которые позволяют снизить $V_{\mathrm{DD}}$ без ухудшения рабочих характеристик [1]. Растущие требования к схемам с высокой плотностью упаковки и зависимость тока утечки от толщины слоя оксида $t_{\text {ок }}$ и порогового напряжения $V_{\text {п }}$ приводят к повышенным требованиям в технологии субмикронных CMOS структур. Существует много факторов, определяющих ток утечки, таких, как ток утечки затвора вследствие очень малой толщины $t_{\text {ок }}$ и под-пороговый ток утечки, вызванный низким значением $V_{\text {п }}$ [2]. Поскольку размеры в полу-

* $\quad$ Работа выполнена при поддержке ITM университета (Гвалиор, Индия) в сотрудничестве с фирмой Cadence System Design (Бангалор, Индия). 